\title{
The Influence of Marketing Communication Tools on Customers' Satisfaction Towards Mobile Phone Service Provider Companies in Jordan
}

\author{
Dr. NOOR FIRDOOS JAHAN ${ }^{1} 8$ (D) $\triangle$ and Mr. Hadi Salah Abdurrahman Atiat ${ }^{2} \mathbf{Q}$ (D) \\ ${ }^{1}$ Professor, R. V. Institute of Management, Bangalore, India \\ ${ }^{2}$ Research Scholar, ISBR Research Centre, Mysore University, India \\ $\triangle$ Corresponding Author: Dr. NOOR FIRDOOS JAHAN, E-mail: noor.firdoos@gmail.com
}

\author{
ARTICLE INFORMATION \\ Received: March 08, 2021 \\ Accepted: May 10, 2021 \\ Volume: 3 \\ Issue: 1 \\ DOI: 10.32996/jbms.2021.3.1.6
}

\section{KEYWORDS}

personal selling, Sales Promotion, Direct Marketing, customers satisfaction

\section{ABSTRACT}

The current study aims to identify the influence of marketing communications tools to achieve customer's satisfaction towards mobile phone service provider companies in Jordan by activating the marketing communications tools to achieve customer's satisfaction and identify the extent of its effectiveness on the mobile phone companies. In this study, the researcher used the descriptive and analytical approach method to describe the phenomenon in question, which evaluates the role of marketing communications tools to achieve customer's satisfaction concerning the mobile phone service providers' companies in the Hashemite Kingdom of Jordan. However, the study population represents all the companies of mobile phone service providers in the Hashemite Kingdom of Jordan, which reached the end of 2019; (3) companies, namely, Zain Jordan Telecommunication Company, Orange Jordan Telecommunication Group, and Umniah Telecommunication Company. Taking into account the limited number of telecommunications companies in Jordan, notably, all telecommunications companies were taken by a comprehensive survey. Accordingly, the study sample represented two categories. The sampling and analysis unit included customers of mobile phone service providers' companies in the Hashemite Kingdom of Jordan. Meanwhile, the researcher has distributed (600) questionnaire on the study sample individuals who are customers of mobile phone service providers' companies in the Hashemite Kingdom of Jordan. The study results showed a significant impact of the marketing communication tools on Jordanian mobile phone service provider companies' customer satisfaction, from customers' point of view.

\section{Introduction}

Marketing communications tools are an exciting and dynamic part as the world has largely changed in the past few years. However, organizations need to ensure that their communications operate effectively and efficiently to reach audiences in markets where communications chaos and competition is high, especially after liberalizing markets and using marketing techniques. The telecommunications' sector is considered one of the most sectors affected by this competition due to the increase in customer's needs and desires, the growth in mobile phone companies, and the big development in the research fields and modern technology. Therefore, this notable progress in performance is reflected in the mobile phone companies. Bearing in mind that these companies are profit-based organizations; hence they need to understand and adopt the marketing communications tools. Whereas, most of the world countries have shown huge interest in mobile phone companies because of their service value in societies

Even though mobile phone companies' main goals are gaining customer trust, they know that there is a great need to pay attention to the effectiveness of the marketing communications tools. This cannot happen without relying on the management of the organizations and marketing communication strategies that can be used. They use marketing communications tools such as personal selling, direct marketing, and promotion. The main goal of activating the marketing communications tools is to

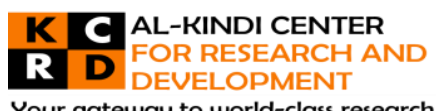

Your gateway to world-class research

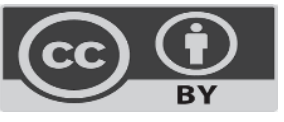

Published by Al-Kindi Center for Research and Development. Copyright (c) the author(s). This open access article is distributed under a Creative Commons Attribution (CC-BY) 4.0 license 
achieve customer's satisfaction, improve the company's positive image in front of the clients, gain their trust and loyalty, create awareness, transfer knowledge, form attitudes, stimulate desires, and the selling impact.

\section{Marketing communications tools}

The tools of marketing communication play a fundamental role in achieving direct and indirect communication with the surrounding environment of mobile phone companies, as these companies face great difficulty at the present time in marketing their services without relying on marketing communication tools because they represent the source of information for the public and help them in making the buying decision and influence the feelings, beliefs and behaviors of current and potential consumers for the purpose of motivating them to buy. Also, there are several marketing communication tools like personal selling, direct marketing, and sales promotion. (Qahtan, 2019).

Demetris and alkis (2012) viewed Sales Promotion as a group of activities such as trade fairs, exhibitions, and showrooms. The next section expands on the topic of sports marketing communications to define the curricula and perspectives of previous and current researchers and provide a comparison with the innovative philosophies of contemporary marketing (Demetris\& Alkis 2012). The American Marketing Association defined it as marketing activities other than personal selling, advertising, or propaganda advertising. Thus, stimulating consumer buying behaviour raises the distributional sufficiency of goods or services. As well as, includes various display methods such as the exhibition and other sales activities that are extraordinary regarding the regular routine (Al-Alaq, 2009).

Methods of sales promotion:

According to Sadiq (2018), Dmour (2008), Sadiq (2018), Adyan (1999) and Percy (2008), methods of sales promotion are:

- $\quad$ Promotions: Providing goods and services by displaying them in films introduce the customer to the best way to use them. This leaves a good impression on the customer and pushes him to buy ( Dmour 2008)

- $\quad$ Free samples: this method is considered as the most used because of its efficiency. It is used to present a new product to the market, but it is more expensive. Also, free samples are provided to the potential customer directly, or they might be accompanied by another good, attached with an explanatory leaflet to know how the sample is used and its benefits (Percy, 2008).

- Coupons: It is one of the traditional methods used to promote sales and is based on providing coupons that enable its holders to obtain a cash amount after purchasing a specific product, or it could be a discount on the price to encourage buying after testing the sample Coupons can be distributed by mail, newspapers, magazines, or attached to the good

- Prices reduction: The Marketing management reduces the price when customers are buying more quantities, and thus, by having a total price for a number of units that is less than the total price of the units if sold separately without the discount, this technique has an effective impact on the consumer because he believes that he has gained an additional unit. (Sadiq 2018)

- $\quad$ Personal Selling

The American Marketing Association defined personal selling as all the personal efforts directed to the customers, with the aim of urging them to make the purchase of the good or service provided to them (Abdulsami, 2007) and face-to-face interaction with one or more potential customers, aiming at presenting the product or service, answering the queries, or responding to the requests and other services (Karthley \& Berolt, 2004).

\section{Goals of personal selling}

Personal selling is considered one of the most important marketing communication tools because it represents a direct communication process, impacting the potential customers and their needs and satisfaction.

Moreover, telecommunications' companies seek to provide an understandable sales force to meet the needs and desires of the target customers. According to Kotler (2006), Sadiq (2018،) and Al-Baba (2011), personal selling seeks to achieve a set of goals, which are as follows:

1- Conclude whole sale process. 2- Serve current customers, through communication with them and satisfy their desires. 3- Find new customers. 4- Inform customers continuously with any changes on the provided services by telecommunications' companies. 5- Train the working salesmen with distributors. 6- Present all the important marketing information to the organization's administration.

\section{Direct Marketing}

There are various definitions and titles of direct marketing. For instance, some identify it as direct marketing, others call it establishing relationships with consumers, and some suggest it is an advertisement urges for a behavior (Stone, 1994). Smith defined direct marketing as theoretical marketing where the consumer buys his needs while sitting in his place without going to 
the place of buying (Smith 2003). Meanwhile, Deblasker (2001) identified direct marketing as the marketing where intermediaries such as salesmen or retailers are not used, but the relationship is directly between the seller and the consumer.

\section{Elements of Direct Marketing}

1 - It is a measurable activity, which means it is related to an individual's response, activity, or specific production.

2- Each party of the exchange parties recognizes the profits arising from the process of participation in this type of exchange, so the customer gets the satisfaction and trust that can develop between the customers and the company, especially when the first realizes and appreciates the personal attention that the company gives to him.

3- The basis of marketing is achieving trust and commitment as basic requirements and helps in building a strong relationship with customers. (Aishush, 2016)

\section{Literature review}

Sadiq Fouad (2018) conducted a study to understand the examined diagnosing the real fact of integrated marketing communications in service's organizations. An exploratory study of the sample's opinions consisted of employees at Korek Telecommunications Company. However, this study highlights the importance and use of the marketing information system in making decisions related to the promotional mix and describing the decision-making process that marketers and managers make using an information marketing system. The organisation's success, namely, in its activities, is always related to the nature of the decisions that marketers and managers make, especially when these decisions are based on facts, data, and information that reflect the marketing environment. Even if the external environment and what needs to be done to confront marketing threats or exploit the opportunities available in the market. Taking into considerations each speed, accuracy and objectivity in data and information, and the need to organize these data and information is important. At this moment, it is necessary to have an effective marketing information system for making the right decisions in many promotional tools the company uses to create, maintain and increase the demand for goods and services

Shuaib (2018) conducted a study to understand the impact of the mix on customer satisfaction with the Islamic insurance company, whereas promotion is considered an important component of customer satisfaction. This study is to study and analyze the promotional mix in the Islamic insurance company to know the strengths and weaknesses and measure customer satisfaction about promotional practices used and make recommendations to the competent authorities to use them in improving the promotional performance. A set of results were selected, the most important of which is that there is a positive impact between all the elements of the promotional mix and the customers' satisfaction, where the values of the correlation coefficient indicated the existence of this relationship, and also a set of general results were reached regarding the frequency of the company's advertisements in various communication means and at places where billboards exist. Also, the company interest to strengthen the relationships with its customers in order to gain their satisfaction.

Qadeer (2016) conducted a study to understand the impact of the promotional mix on the competitive advantage in Zain Telecommunications Company in Jordan. It aims to clarify the marketing relationship between the company and the customer, to analyze the marketing mix dimensions and manage the relationship with the customer to develop a marketing mix system that achieves a competitive advantage for the company under study and try to control a larger share of the market through occupying advanced positions. Also, the study concluded that Zain Telecommunications Company relies on advertising to gain a strong competitive position by increasing its share of the telecommunications market and growing its sales. Additionally, Zain Telecommunications' public relations and customer inquiries service enhanced the company's positive image and achieved customer satisfaction. Zain Company's direct selling window performance effectively reduced the waiting queues. Also, the large number of sales agents contributed to the increase in sales, as a sequence it was found that the application of advanced programs concerned with managing the relationship with the customer in order to reach the good characteristic and the spoken word by customers, also the continuous training of the workers provided that the programs include skills of development and communication with people by applying marketing methods and tools, as well as the art of marketing in the field of services.

Nour Al-huda (2016) conducted a study to identify marketing telecommunications' role in providing new services to Algeria Telecommunication. Thus by answering the main research question "What is the extent of integrated marketing communications' contribution in providing new services to Algeria Telecommunication" the researcher utilized the questionnaire to achieve the objectives of the study. The study population consisted of Algeria telecommunications company's employees, where (50) sample questionnaires were distributed to these employees. Accordingly, (44) questionnaires were retrieved, i.e. (88\%). However, the questionnaire consisted of 32 questions divided into two main sections: the first section, 14 paragraphs about the real situation regarding marketing communications in Algeria Telecommunications Company. The second section, 18 paragraphs about providing new services and the appropriate promotional tools. The researcher emptied and analyzed the questionnaire through 
the Statistical Package for the Social Sciences (SPSS). In contrast, different statistical methods and tools were used, such as median and standard deviations Keywords: Integrated marketing communications, marketing communication.

Qaziz (2013) conducted a study to understand the aims to examine the importance of the promotionally mixed elements' role used by the various telecommunication companies in Algeria. Besides, it measures those companies' awareness in charge officers by applying modern promotional methods towards improving their services. Meanwhile, the study adopted the integrated approach in the applied research to achieve the correlation and connectivity between the theoretical aspect and its applied reality through the descriptive and analytical approach. Thus, using the questionnaire to measure the study hypotheses validity, a random sample of (60) was studied; the sample is Algeria Telecommunications customers in Ouargla area only. The study concluded that there is a positive effect of the promotional mix elements on the company's services, which contributes to improving these services, highlighting other contribution factors.

Kavaldeep and Neha (2016) conducted a study to understand that the increase in the number of players in cellular telephony has raised the expectation level of customers, compelling firms to devise strategies to gain a competitive edge. Thus, the main objective of this research is to comparatively study employees and customer's awareness regarding marketing communication tools adopted by Bharti Airtel and Idea Cellular in eastern Rajasthan. In the present study communication tools pertaining to advertising, sales-promotion, personal selling, direct marketing, events and public relations have been considered and analyzed. The present research will also attempt to explore the sources of information referred to by customers while opting for telecommunication services. The study will involve a sample of 250 existent customers and 25 employees for Bharti Airtel and Idea Cellular, respectively and the methodology employed will be structured questionnaire for customers and employees separately with reference to eastern Rajasthan. By identifying the strategic issues that affect customer decisions, the present research will contribute to understanding the influence of communication tools on customers. It would also enable marketing managers to identify the impact of these dimensions and concentrate the firm's efforts on those factors that enhance customer awareness. It is an exploratory study.

Arno (1995) conducted a study to understand the examination of the development of phone services infrastructure and the role of wired and wireless technology. This study shows the role of cost and its effectiveness in the field of wireless phones compared to wired phones. Knowing that the World Bank reports were used in this study, and the need for telecommunications to analyze the role and suitability of wireless technology As well as its availability and superiority over wired technology Ordinarily, the most important findings of the study are that the telecommunications infrastructure should be viewed as a promotional tool that contributes in the national development and not only as a simple service tool that relies on high capacity and its direct availability, and that wireless technology must be used extensively, especially in residential areas in order to provide comprehensive and global coverage for the served areas.

Thoret Amaulat (1996) conducted a study to understand investigated the idea of developing a cell phone in France and comparing it to the same service in Germany and U.K. This study aimed to clarify the effect of social factors on shaping the market in France and compare it to those in Germany and U.K. The study found that the French market went after Germany, which ranked first. But it overtakes the British market in this area, and thus the level of development in the three markets is not equal. Meanwhile, this study emphasized the importance of social factors in the French market and how this environment prevented the growth of the market before 1995

\section{Research objectives}

1. To find out the various marketing communication tools used by the mobile service provider companies at Jordan

2- To study the influence of marketing communications tools on customers' satisfaction towards mobile phone service provider companies in Jordan.

\section{Research methodology}

The study aims to Influence of marketing communications tools to achieve customer's satisfaction towards mobile phone service provider companies in Jordan. Population groups were selected for this study. is consisted of the customers of mobile phone companies in the Hashemite Kingdom of Jordan. Here and because of the lack of a framework for the study population (an unlimited community) and the difficulty of conducting a comprehensive inventory of all customers in the companies of mobile phone service providers, according to (Sekaran \& Bougie, 2012), a sample size of (384) views is the minimum for a sample representing such a community. With reference to some similar studies, such as the study of Musa (2016), the study sample was represented by Zain Jordan Telecommunication Company customers, namely, (440) questionnaires were distributed. As a result of the similarity in the sample size between the current study and the previous studies, a sample size is determined as 600 participants. The researcher distributed (600) questionnaires to the individuals of the study sample who are customers of mobile phone telecommunications companies which are located in the capital Amman, where (572) questionnaires were retrieved, of which (42) were non-analyzable questionnaires, so the number of the recovered and statistically analyzed questionnaires reached 
(530), i.e. (88.3\%) of the total distributed questionnaires, which is a statistically acceptable percentage. The study population is represented in all mobile phone service provider companies in the Hashemite Kingdom of Jordan, which reached the end of 2019 (3) companies: Zain Jordan Telecommunications Company, Jordanian Telecommunications Company (Orange) Umniah Telecommunications Company. Due to the limited number of telecommunications companies in Jordan, all telecommunications companies were included by the comprehensive survey to represent the study sample.

\section{Data analysis}

To test the suitability of the study model for linear regression analysis and parametric tests, a multicollinearity test was performed, where this phenomenon indicates the existence of a near-perfect linear correlation between two or more variables, which inflates the coefficient of determination R2 value and makes it greater than its actual value. According to the study model, the value of Pearson correlation coefficient between the independent variables was measured and in particular each variable concerned with customers and workers, and thus as follows:

Table 1.1: The correlation matrix for the independent variables in the customers' model

\begin{tabular}{|r|r|r|r|r|r|}
\hline Variables & Advertising & $\begin{array}{r}\text { Personal } \\
\text { selling }\end{array}$ & $\begin{array}{r}\text { Public } \\
\text { relations }\end{array}$ & $\begin{array}{r}\text { Direct } \\
\text { marketing }\end{array}$ & $\begin{array}{r}\text { Sales } \\
\text { promotion }\end{array}$ \\
\hline Advertising & 1.000 & & & & \\
\hline Personal selling & ${ }^{*} 0.619$ & 1.000 & & & \\
\hline Public relations & ${ }^{*} 0.638$ & ${ }^{* *} 0.523$ & 1.000 & & \\
\hline Salect marketing & ${ }^{* *} 0.758$ & ${ }^{* \star} 0.695$ & ${ }^{* *} 0.617$ & 1.000 & \\
\hline${ }^{*} 0.780$ & ${ }^{* \star} 0.596$ & ${ }^{* *} 0.606$ & ${ }^{* *} 0.701$ & 1.000 \\
\hline
\end{tabular}

Significant at the significance level $\left.0.01{ }^{(* *}\right)$

As can be seen from the table (1.1), the highest correlation coefficient was between the two variables (advertising) and (sales promotion), which reached (0.788), and this is less than (0.80), so this indicates the absence of the multicollinearity phenomenon among the variables, where the value of the correlation coefficient which exceeds $(0.80)$ is considered an indicator of a high multicollinearity problem (Guajarati, 2004, 359). In order to confirm the previous result, the variance inflation factor was calculated for each of the independent variables to ensure that there is no multicollinearity; thus, the results were as follows:

Table 1.2: Results of multiple correlation test between the independent variables in the customers' model

\begin{tabular}{|c|c|c|}
\hline Variables & $\begin{array}{l}\text { Variance } \\
\text { Inflation } \\
\text { Factor }\end{array}$ & Tolerance \\
\hline Advertising & 3.570 & 0.280 \\
\hline Personal selling & 2.039 & 0.490 \\
\hline Public relations & 1.882 & 0.531 \\
\hline Direct marketing & 3.131 & 0.319 \\
\hline Sales promotion & 2.911 & 0.344 \\
\hline
\end{tabular}

As can be seen from the table (1.2), the values of the variance inflation factor were all greater than the number 1 and less than the number 10, as well as the tolerance value was confined between the number 0.1 and the number 1 , which indicates that there is no multicollinearity problem among the study variables.

\section{Testing of Hypothesis}

HO: "There is no statistically significant role of marketing communication tools in achieving customer's satisfaction towards mobile phone service provider companies in the Hashemite Kingdom of Jordan, thus, from the customer's point of view."

Thus, in order to test this hypothesis, Multiple Linear Regression analysis was used. The following table shows the results of the Multiple Linear Regression Analysis test: 
Table 1.3: Regression coefficients to test hypothesis $(\mathrm{H} 0)$

\begin{tabular}{|c|r|r|r|r|}
\hline $\begin{array}{c}\text { Marketing } \\
\text { communication } \\
\text { tools }\end{array}$ & coefficients (B) & Standard error & $\begin{array}{r}\text { Calculated value } \\
\text { T }\end{array}$ & Sig (T) \\
\hline Advertising & 0.315 & 0.049 & 6.428 & 0.000 \\
\hline Personal selling & 0.077 & 0.039 & 2.005 & 0.046 \\
\hline Public relations & 0.244 & 0.036 & 6.827 & 0.000 \\
\hline Direct marketing & 0.204 & 0.048 & 4.258 & 0.000 \\
\hline Sales promotion & 0.173 & 0.049 & 3.495 & 0.001 \\
\hline
\end{tabular}

Interpretation:

Table (1.3) shows the regression coefficients values of each marketing communication tool, and it is evident from the table that there is a significant impact for all tools, as the significance level values reached less than 0.05 . According to the results of the table (1.3) it can be said that there is an impact of the marketing communication tools used by mobile phone service provider's companies in Jordan on customer satisfaction, from customers' point of view, and this leads to reject (null) hypothesis and accept the alternative one, which states: "There is a statistically significant role of marketing communication tools in achieving customer's satisfaction towards mobile phone service provider companies in the Hashemite Kingdom of Jordan, thus, from the customer's point of view."

Therefore, to measure the importance of marketing communication tools in achieving customer satisfaction and determine the most effective tool in achieving customer satisfaction for mobile phone service provider companies in Jordan, from the customer's perspective. Stepwise Linear Regression analysis was used, and the following table shows the results:

Table 1.4: Results of the Stepwise Linear Regression analysis related to the hypothesis $(\mathrm{H} 0)$

\begin{tabular}{|c|c|c|c|c|c|c|c|}
\hline Model & $\begin{array}{c}\text { Marketing } \\
\text { Communication } \\
\text { Tools }\end{array}$ & $\begin{array}{l}\text { coefficients } \\
\text { (B) }\end{array}$ & $\begin{array}{c}\text { Calculated } \\
\text { value } \\
\text { T }\end{array}$ & $\begin{array}{c}\text { Sig } \\
T\end{array}$ & $\begin{array}{c}\text { Calculated } \\
\text { value F }\end{array}$ & $\begin{array}{c}\mathbf{R}^{\mathbf{2}} \\
\text { Coefficients } \\
\text { of } \\
\text { Determinati } \\
\text { on } \\
\end{array}$ & $\begin{array}{c}\text { Sig } \\
\mathbf{F}\end{array}$ \\
\hline First & Advertising & 0.310 & 16.588 & 0.000 & 275.166 & 0.637 & 0.000 \\
\hline \multirow[t]{2}{*}{ Second } & Advertising & 0.233 & 12.489 & 0.000 & \multirow[b]{2}{*}{221.027} & \multirow[b]{2}{*}{0.739} & \multirow[b]{2}{*}{0.000} \\
\hline & Public relations & 0.157 & 7.827 & 0.000 & & & \\
\hline \multirow[t]{3}{*}{ Third } & Advertising & 0.170 & 7.470 & 0.000 & \multirow{3}{*}{170.832} & \multirow{3}{*}{0.768} & \multirow{3}{*}{0.000} \\
\hline & Public relations & 0.161 & 8.460 & 0.000 & & & \\
\hline & Direct marketing & 0.094 & 4.372 & 0.000 & & & \\
\hline \multirow[t]{4}{*}{ Fourth } & Advertising & 0.152 & 6.484 & 0.000 & \multirow{4}{*}{133.933} & \multirow{4}{*}{0.777} & \multirow{4}{*}{0.000} \\
\hline & Public relations & 0.125 & 5.317 & 0.000 & & & \\
\hline & Direct marketing & 0.077 & 3.462 & 0.001 & & & \\
\hline & Sales promotion & 0.080 & 2.483 & 0.014 & & & \\
\hline \multirow[t]{5}{*}{ Fifth } & Advertising & 0.141 & 5.947 & 0.000 & \multirow{5}{*}{110.928} & \multirow{5}{*}{0.784} & \multirow{5}{*}{0.000} \\
\hline & Public relation & 0.120 & 5.141 & 0.000 & & & \\
\hline & Direct marketing & 0.051 & 2.062 & 0.041 & & & \\
\hline & Sales promotion & 0.078 & 2.465 & 0.015 & & & \\
\hline & Personal selling & 0.076 & 2.236 & 0.027 & & & \\
\hline
\end{tabular}


Table (1.4) pointed out that marketing communication tools (advertising, personal selling, public relations, direct marketing, and sales promotion) are significant and have an impact on achieving customer satisfaction, as their impact was significant at a significance level less than 0.05 , with a variance in the level of significance and impact. Whereas it is clear that the (advertising) tool ranked first, and it interprets (57.5\%) of the change in achieving customer satisfaction, and after listing the (public relations) tool in the second model, the percentage increased by (6.0\%) to reach (63.5). Then listing the (Direct Marketing) tool in the third model led to an increase of (2.6\%) to become (66.1\%) Also, the next listing of the (Sales Promotion) tool in the fourth model increased the interpretation rate by $(0.8 \%)$ to reach $(66.9 \%)$, and finally, listing the (personal selling) tool in the fifth model caused an increase in the interpretation percentage by $(0.3 \%)$ to become $(67.2 \%)$.

\section{Results}

The hypothesis showed a significant impact of the marketing communication tools on Jordanian mobile phone service provider companies' customer satisfaction, thus from customers' perspectives. It was demonstrated that marketing communication tools (personal selling, direct marketing, and sales promotion) significantly impact achieving customer satisfaction. Their impact was significant at a significance level less than 0.05 , with a variance in the level of significance and impact. It is clear that the (direct marketing) tool ranked first, and it interprets (57.5\%) of the change in achieving customer satisfaction. This result corresponds with the study of Qadeer (2016), the (direct marketing) tool has an impact on enhancing the competitive advantage of Zain Telecommunications Company, and after adding the sales promotion tool in the second model, the percentage increased by (6.0\%) to reach (63.5). This result agrees with Sadeq's (2018) study "Diagnosing the integrated marketing communication situation in the services organizations", His study outlined that sales promotion tool has an impact on the situation of the marketing communications, it also ranked second. Meanwhile, listing the (personal selling) tool in the third model led to an increase of (2.6\%) to become (66.1\%). This result corresponds with the study of Al-Baba (2011) since it revealed that (personal selling has an impact on the subscribes purchase behaviour of mobile phone telecommunication companies which was ranked third

The results showed that there is a significant impact of the marketing communication tools on Jordanian mobile phone service provider companies' customer satisfaction, from customers' point of view.

\section{Recommendations}

1-The need for the workers of the mobile phone senvice providers' companies in the Hashemite Kingdom of Jordan to meet the customers with a smile, treat them politely and courteously, and enjoy a good-looking manner.

2-The necessity for Jordanian mobile phone service provider companies' participation in the responsibility to serve the needs of society as they participate in building some public facilities and supporting the education and sports sector.

3-The need for the attention of the mobile phone service providers' companies in the Hashemite Kingdom of Jordan website and includes all their services and offers.

4-The mobile phone service providers' companies in the Hashemite Kingdom of Jordan need to pay their attention to run prize withdraws when customers subscribe to their offers.

5-It is important for mobile phone service providers' companies to qualify and train their workers to achieve customer satisfaction.

Funding: This research received no external funding.

Acknowledgements: We acknowledge the support from the mobile phone service provider's companies in the Hashemite Kingdom of Jordan for permitting us to conduct this research and also helping us in the whole process of data collection.

Conflicts of Interest: The authors declare no conflict of interest".

\section{References}

[1] Aichoush, A. (2017). The Role of the Promotional Policies in the Marketing of Electronic Products. [PhD Thesis], Commercial Sciences Specialist, University of Batna

[2] Al-Alaq, B. (2003). Marketing in the Internet \& the Digital Economy" Cairo, Arab Organization for Administrative Development

[3] Al-Alaq, B. (2009). Fundamentals \& Applications of Electronic and Traditional Promotion, an Integrated Introduction. Dar Al-Yazouri for Scientific Publishing \& Distribution, Amman, Jordan

[4] Al-Bakri, T. (2006). Marketing Communications \& Promotion. Dar Al-Hamed for Publishing \& Distribution, First Edition, Amman, Jordan

[5] Al-Bakri, T (2015). Marketing Communications \& Promotion, Dar Al-Hamed for Publishing \& Distribution, Second Edition, Amman, Jordan

[6] Al-Sarabi, A. (2011). Tourism and Hotel Marketing \& Sales. First Edition ,Dar Jareer For Publishing \& Distribution, Amman, Jordan.

[7] Al-Zoubi, F. (2013). Marketing Communications Second Edition, Dar Al Masirah for Publishing, Distribution \& Printing, Amman, Jordan

[8] Blythe. J. (2000). Marketing communications. London: person education limited

[9] Hassan, K. (2008). Sales Management. Cairo, Dar Al-Nahda Al-Arabia

[10] Jabots, F. (2008). The Integrated Marketing Mix" bto b. magazine 14 July

[11] Jarrar, D. (2012). Marketing Communications. First Edition, Cairo, Egypt, United Arab Company for Marketing and Supplies. 
[12] Polick. M. (2009). What is Direct Marketing. Wise.GEEK. 29 July

[13] Saedani, S., \& Ben Saeed, M. (2019). The Role of the Marketing Information System in Making Decisions Regarding the Elements of the Organization's Promotional Mix" University of JilaliYabis, Sidi Bel Abbes, Algeria

[14] Shimp. T. (2000). Advertising promotion. the Dryden press 